\title{
Lowering of plasma triiodothyronine level and sympathetic activity does not alter hypoalbuminaemia in rats fed on a diet of low protein concentration
}

\author{
Ana Lydia Sawaya* and Peter G. Lunn \\ Dunn Nutritional Laboratory, Downham's Lane, Milton Road, Cambridge CB4 IXJ, UK
}

(Received 5 August 1997-Revised 12 November 1997-Accepted 5 December 1997)

\begin{abstract}
Previous studies have described high plasma triiodothyronine $\left(T_{3}\right)$ concentrations and sympathetic activity in rats fed on low-protein diets. The present investigation examined how the nutritional status of rats fed on a low-protein diet was affected when these hormonal changes were reduced by drug administration. The low-protein diet (LP group) prevented growth, reduced plasma albumin levels, elevated plasma $\mathrm{T}_{3}$ concentration, and increased both the weight of the interscapular brown adipose tissue (BAT) and the activity of BAT cytochrome $c$ oxidase (EC 1.9.3.1). Lowering the plasma $T_{3}$ concentration (with carbimazole; CA group) elevated the plasma insulin concentration, promoted a small increase in the plasma albumin concentration and caused weight gain in comparison with the LP group. Reduction of sympathetic activity (with $\alpha$-methyl-p-tyrosine; MT group) promoted a small elevation in plasma albumin concentration accompanied by a diminished $T_{3}$ concentration, BAT weight, and an increase in fat deposition in relation to LP rats. In a second experiment, simultaneous lowering of the plasma $T_{3}$ concentration and sympathetic activity (CA/MT group) resulted in weight gain associated with elevated plasma insulin concentration and fat deposition and a marked reduction in BAT cytochrome $\mathrm{c}$ oxidase activity. However no change in the hypoalbuminaemia was observed. The results of the present study suggest that in spite of the previously described increase in metabolic rate in rats fed on a diet with low-protein concentration when compared with controls, the mechanisms involved in the control of BAT activity and fat deposition seem to be independent of those which cause liver protein depletion and hypoalbuminaemia.
\end{abstract}

Hypoalbuminaemia: Protein intake: Triiodothyronine

The experiments of Lunn \& Austin $(1983 a, b)$ and Sakuma et al. (1987) have demonstrated that hypoalbuminaemia, the most characteristic feature of kwashiorkor, develops in rats fed on a low-protein diet when they consume energy in excess of requirements for growth and maintenance. Data from balance studies have shown that for hypoalbuminaemia to occur, not only had dietary protein to be inadequate, it was also necessary for energy consumption to be in excess of requirements for the protein-limited growth rate (Lunn \& Austin, 1983a,b). In addition, Lunn \& Austin $(1983 b, c)$ found, in their studies in rats fed at constant protein intake, a strong ( $r$ 0.93) negative association between the plasma concentrations of albumin and triiodothyronine $\left(T_{3}\right)$ with various levels of energy restriction. These findings raised the suggestion that the way in which the organism deals with the energy surfeit might interfere with protein metabolism and cause hypoalbuminaemia in rats fed on diets with a low protein concentration. In keeping with this picture, the two hormones most directly concerned in energy dissipation, $T_{3}$ and noradrenaline, occur in elevated amounts in rats and other animals fed on low-protein diets (Tulp et al. 1979; Lunn \& Austin, 1983b,c; Kenovian et al. 1984; Vander Tuig \& Romsos, 1984; Carew \& Alster, 1997).

Both hormones are also known to exert effects on $\mathrm{N}$ metabolism. The role of thyroid hormones in $\mathrm{N}$ metabolism is complex and even in individual tissues, such as skeletal muscle and liver, their action is far from clear (Grofte $e t$ al. 1997). In euthyroid or hypothyroid states, both $T_{3}$ and thyroxine $\left(\mathrm{T}_{4}\right)$ are anabolic, but their presence increases the rates of both synthesis and breakdown of muscle tissue (Tischler, 1981; Brown \& Millward, 1983). In regard to

\footnotetext{
Abbreviations: BAT, brown adipose tissue; CA group, group treated with carbimazole; CA/MT group, group treated with carbimazole and $\alpha$-methyl-ptyrosine; LP group, group fed on a low-protein diet; MT group, group treated with $\alpha$-methyl-p-tyrosine; P:E, protein energy: total energy; $\mathrm{T}_{3}$, triiodothyronine; $\mathrm{T}_{4}$, thyroxine.

*Corresponding author: Dr Ana Lydia Sawaya, present address: Escola Paulista de Medicina, Depto. de Fisiologia, Disc. de Fisiologia Endócrina, V. Clementino, 04023-060, São Paulo, Brazil; fax +55 118728631 , email ANA.FISI@EPM.BR
} 
noradrenaline, there are few reports concerning its effects on muscle protein turnover. However, according to Tischler (1981) this hormone reduces proteolysis in skeletal muscle, an action which is inhibited by addition of the $\beta$-blocker propranolol. In addition, several authors (Emery et al. 1984; Bates \& Pell, 1991) have demonstrated increased protein deposition and raised protein synthesis rate in skeletal muscle of rats treated with the $\beta$-agonist clenbuterol.

To investigate the effects of lowering the plasma $\mathrm{T}_{3}$ level and sympathetic activity on skeletal muscle protein, plasma albumin levels, brown adipose tissue (BAT) activity, and body fat, we administered carbimazole and $\alpha$-methyl-ptyrosine, known to inhibit thyroid hormone and catecholamine synthesis respectively, to rats fed on a diet of low protein concentration; by reducing these hormones we expected to improve liver status and raise the plasma albumin concentration. Thus, the objective of the present study was to investigate if the increases in $T_{3}$ and sympathetic activity could also exert effects on $\mathrm{N}$ metabolism by reducing skeletal muscle proteolysis and limiting amino acid supply to the liver, in rats fed on lowprotein diets.

\section{Materials and methods}

Males from an inbred, specific-pathogen-free strain of hooded rats maintained at the Dunn Nutritional Laboratory were used in the experiments. Care of the rats was supervised by veterinarians and was in accordance with the policies of the Dunn Nutrition Unit, University of Cambridge, UK. Animals were weaned at 3 weeks on to a synthetic casein-based diet with a protein energy: total energy ( $P: E$ ) value of 0.20 (Table 1 ) for 1 week before the experimental procedures began. Two studies were undertaken: the first examined the effects of separate inhibition of $T_{3}$ and catecholamines while the second investigated the result of simultaneous inhibition of the two hormones. The hormone inhibitors were administered by mixing them with the animals' food.

Thyroid hormone synthesis was inhibited with carbimazole in the form of tablets of neomercazole (Nicholas, London, UK) which were powdered, and then carefully mixed into the diet to give a carbimazole concentration of $50 \mathrm{mg} / \mathrm{kg}$ food. However, since it has been shown that carbimazole at various concentrations decreases plasma thyroid hormones with marked impairment in albumin

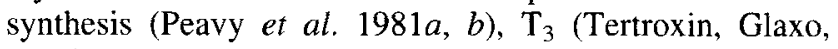
London, UK) was added to the food at $10 \mu \mathrm{g} / \mathrm{kg}$ diet. Although it is important to acknowledge the possibility of hypothyroxinaemia, some pieces of evidence support the decision to add $T_{3}$ and not $T_{4}$ to the diet mixture. First, previous studies have shown that $T_{3}$ is elevated in protein deficiency while $\mathrm{T}_{4}$ is decreased (Carew \& Alster, 1997). Second, $T_{3}$ and not $T_{4}$ was inversely associated with plasma albumin levels (Lunn \& Austin, 1983b,c). Third, skeletal muscle and liver are more sensitive to blood $T_{3}$ levels than to $T_{4}$. In addition, the main purpose of the present drug manipulation was to prevent the rise in $T_{3}$ levels observed in rats fed on low-protein diets. On the other hand, we are aware of, and believe it is important to state, the limitations of this kind of drug treatment which certainly cause many other hormonal and metabolic alterations which it is not possible to control for.

Drugs were added to the weaning diet because previous pilot studies had shown that addition of carbimazole was most effective in the reduction of plasma thyroid hormones when administered before the change to the low-protein diet. Adding carbimazole to the weaning diet for $3 \mathrm{~d}$ before offering the low-protein diet prevented the rise in plasma $\mathrm{T}_{3}$ concentration which occurs when rats are given free access to such a diet, maintaining its concentration within the normal range. Catecholamine production was lowered with $\alpha$-methyl-p-tyrosine (Sigma, Poole, Dorset, UK) which was mixed with the food to give a concentration of $5 \mathrm{~g} / \mathrm{kg}$ diet. The drug concentration was chosen after pilot

Table 1. Composition ( $\mathrm{g} / \mathrm{kg}$ diet) of the weaning and low-protein diets given to rats

\begin{tabular}{lcc}
\hline Constituent & Weaning & Low-protein \\
\hline Casein & 210 & 31.5 \\
Cystine & 3 & 0.45 \\
Sucrose & 355 & 444.5 \\
Starch & 355 & 444.5 \\
Maize oil & 30 & 30 \\
Salt mixture & 50 & 50 \\
Total & 1003 & 1001 \\
B-vitamin and choline chloride mixture $(\mathrm{ml} / \mathrm{kg}) \dagger$ & 10 & 10 \\
Fat-soluble vitamin mixture & 1 dose $/$ week & 1 dose $/$ week \\
Energy content $(\mathrm{MJ} / \mathrm{kg})$ & 16.70 & 16.70 \\
Carbohydrate $(\mathrm{g} / \mathrm{kg})$ & 701 & 879 \\
Protein $(\mathrm{g})$ & 209 & 31 \\
\hline
\end{tabular}

- Containing $(\mathrm{g} / \mathrm{kg})$ : calcium carbonate 250 , calcium hydrogen phosphate 325 , disodium hydrogen phosphate 185 , potassium chloride 205 , magnesium sulfate 4.5 , ferric citrate 4.35 , copper sulfate 0.375 , zinc carbonate 0.75 , potassium lodate 0.025 (commercially prepared by Arthur H. Cox, Brighton, Sussex, UK).

+ Containing: choline chloride $2 \mathrm{~g}$, calcium pantothenate $20 \mathrm{mg}$, thiamin $3 \mathrm{mg}$, pyridoxine $3 \mathrm{mg}$, riboflavin $3 \mathrm{mg}$, nicotinamide $25 \mathrm{mg}$, biotin $0.1 \mathrm{mg}$, cyanocobalamin $0.05 \mathrm{mg}$.

¥ Each rat received weekly doses of fat-soluble vitamins in arachis oil containing: retinyl acetate $344 \mu \mathrm{g}$, ergocalciferol $5 \mu \mathrm{g}$, dl- $\alpha$-tocopherylacetate $2 \mathrm{mg}, 2$-methyl-1,4-naphthoquinone $0.05 \mathrm{mg}$. 
dose-response studies were performed using three different doses: 1,5 and $6 \mathrm{~g} / \mathrm{kg}$ diet. No significant metabolic changes were observed when rats fed on a low-protein diet were treated with $\alpha$-methyl- $p$-tyrosine at $1 \mathrm{~g} / \mathrm{kg}$ diet; however, treatment with $6 \mathrm{~g} / \mathrm{kg}$ diet markedly impaired weight gain (AL Sawaya and PG Lunn, unpublished results). Administration of the drug at $5 \mathrm{~g} / \mathrm{kg}$ diet, on the other hand, proved effective at lowering sympathetic activity since it promoted both a marked decrease in plasma $T_{3}$ concentration and a simultaneous increase in body fat. A better description of its effects is presented in Table 2.

At day 12 after weaning, rats were divided into groups of six. Those in the control group continued with the same diet for the following 2 weeks and $3 \mathrm{~d}$ of the experiment; those in the LP group received the weaning diet for a further $3 \mathrm{~d}$, but were then fed for 2 weeks on a diet of low protein concentration, P:E 0.03 (Table 1). Thyroid-inhibited animals (CA group) received similar dietary treatment to the LP group but with carbimazole and $\mathrm{T}_{3}$ added to the weaning diet for $3 \mathrm{~d}$ and then to the low-protein diet for 2 weeks. Those treated with $\alpha$-methyl-p-tyrosine had this compound added to their low-protein diet only (MT group).

In the second experiment three groups were studied, starting on day 7 after weaning. The first group was given free access to a low-protein diet for 2 weeks (LP group). The second group received both hormone suppressers (CA/MT group) added to the food as follows: $3 \mathrm{~d}$ of weaning diet mixed with carbimazole and $T_{3}(50 \mathrm{mg} / \mathrm{kg}$ diet plus $10 \mu \mathrm{g} / \mathrm{kg}$ diet respectively), then 2 weeks of lowprotein diet mixed with carbimazole, $\mathrm{T}_{3}$ plus $\alpha$-methyl- $p$ tyrosine $(5 \mathrm{~g} / \mathrm{kg}$ diet). A third group, pair-fed with the CA/MT-treated animals, was also included (pair-fed group), receiving the low-protein diet in amounts calculated daily to match the intake of the CA/MT group.

During the experimental period the rats were individually housed in wire cages fitted with trays to collect food spillage. Ambient temperature was kept at $23 \pm 2^{\circ}$ and a $12 \mathrm{~h}$ light-dark cycle was maintained. Food and water were freely available. Animals were weighed and their food consumption recorded daily.

At the end of the experimental period, rats were killed between 10.00 and 11.00 hours by exsanguination under diethyl ether anaesthesia. Blood was collected into heparinized tubes and the resulting plasma stored at $-20^{\circ}$ until required for analysis. Interscapular BAT was removed into ice-cold SHE buffer $(0.25 \mathrm{M}$-sucrose, $0.1 \mathrm{mM}$ HEPES, $0.1 \mathrm{M}$-dipotassium EDTA, $\mathrm{pH}$ 7.2) and separated from adhering muscle and white fat. It was then blotted, weighed and homogenized and kept at $4^{\circ}$ for the assay of cytochrome c oxidase ( $E C$ 1.9.3.1) activity. The liver and the gastrocnemius muscle from one leg were removed and weighed, and portions were taken into small tin capsules for $\mathrm{N}$ analysis using an automated $\mathrm{N}$ analyser (Dumas Analyzer, Carlo Erba, Erba Science, Swindon, Wilts., UK). Protein was calculated as $\mathrm{N} \times 6.25$.

\section{Assays}

Cytochrome c oxidase was assayed in BAT homogenates by following the oxidation of reduced cytochrome $c$ spectrophotometrically at $550 \mathrm{~nm}$ according to the method of Yonetani \& Ray (1965). Plasma albumin was determined using a bromocresol-green technique (Sawaya \& Lunn, 1985). Concentrations of $T_{3}$ and insulin in plasma were measured by radioimmunoassay using a kit supplied by Amersham International (Amersham, Bucks., UK).

An estimate of the carcass composition was obtained by freeze-drying the animal carcass. Body water $(\mathrm{g} / \mathrm{kg})$ and body fat $(\mathrm{g} / \mathrm{kg})$ were calculated from total body water content measured by desiccation. It was assumed that water constituted $732 \mathrm{~g} / \mathrm{kg}$ of the fat-free wet weight of the animals (Sheng \& Huggins, 1979), according to the equation: $\%$ fat $=100(1-(\%$ total body water $/ 0.732))$. Then the percentage of fat was converted into total body fat by the equation: $\%$ fat $\times$ body weight $/ 100$. Identical weights on two successive days was the criterion routinely used to check for complete dehydration of freeze-dried

Table 2. Body weight, food intake and metabolic variables in rats fed on a weaning diet (control), a low-protein diet alone (LP), a low-protein diet plus carbimazole and triiodothyronine (CA) or a low-protein diet plus $\alpha$-methyl-p-tyrosine (MT)*

(Values are means for six rats with their pooled standard error)

\begin{tabular}{|c|c|c|c|c|c|c|}
\hline \multirow[b]{2}{*}{ Group... } & \multirow[b]{2}{*}{ Control } & \multirow[b]{2}{*}{ LP } & \multirow[b]{2}{*}{ CA } & \multirow[b]{2}{*}{ MT } & \multicolumn{2}{|c|}{ ANOVA } \\
\hline & & & & & SEM & $P$ \\
\hline Initial body wt (g) & 109 & 117 & 119 & 131 & 5 & NS \\
\hline Weight gain $(\mathrm{g})$ & $91 \cdot 7^{\mathrm{a}}$ & $-0.2^{b}$ & $8.8^{\mathrm{c}}$ & $-2.0^{\mathrm{b}}$ & 1.9 & $<0.001$ \\
\hline \multicolumn{7}{|l|}{ Food consumption: } \\
\hline$(g / d) \dagger$ & $19 \cdot 0$ & $15 \cdot 9$ & $16 \cdot 3$ & $15 \cdot 3$ & 1.0 & 0.05 \\
\hline$\left(\mathrm{g} / \mathrm{d}\right.$ per kg body $\left.\mathrm{wt}^{0.75}\right)$ & $75 \cdot 6$ & 79.3 & 78.4 & 70.6 & 4.4 & NS \\
\hline Plasma albumin $(\mathrm{g} / \mathrm{l})$ & $31 \cdot 1^{a}$ & $24.5^{\mathrm{b}}$ & $25.8^{c}$ & $26 \cdot 3^{c}$ & 0.3 & $<0.001$ \\
\hline Plasma triidothyronine $(\mu \mathrm{g} / \mathrm{l})$ & $1 \cdot 15^{\mathrm{a}}$ & $1.44^{\mathrm{b}}$ & $1.13^{\mathrm{a}}$ & $0.81^{\mathrm{a}}$ & 0.04 & $<0.001$ \\
\hline Plasma insulin $(\mathrm{mU} / \mathrm{l})$ & $16 \cdot 5^{\mathrm{a}}$ & $17 \cdot 7^{\mathrm{a}}$ & $38 \cdot 0^{\mathrm{b}}$ & $23.5^{\mathrm{ab}}$ & 4.5 & 0.03 \\
\hline Interscapular BAT (mg/kg body wt) & $3200^{\mathrm{a}}$ & $5680^{\mathrm{b}}$ & $4960^{\mathrm{bc}}$ & $4390^{c}$ & 233 & $<0.001$ \\
\hline
\end{tabular}

BAT, brown adipose tissue.

a,b,c Mean values within a row not sharing a common superscript letter were significantly different, $P<0.05$ (ANOVA followed by the Newman-Keuls procedure)

* For details of diets and procedures, see Table 1 and pp. 456-457.

+ Food intake is expressed as the average of daily measurements over 2 weeks. 
samples. This method allows comparison of rats in the different groups and has been further discussed by Lunn \& Austin (1983b).

Statistical differences were assessed using one-way ANOVA. The Newman-Keuls test was performed subsequently for comparisons between groups.

\section{Results \\ Treatment with low-protein diet}

It is clear from the weight gain results shown in Table 2 that dietary protein deficiency (LP group) resulted in a marked reduction in growth performance. Although food consumption measured as $\mathrm{g} / \mathrm{d}$ was lower in the LP group than in the rapidly growing control rats, the differences were not significant according to the Newman-Keuls test for pair comparisons. Also, when food intake was corrected for metabolic body weight, it was clear that no significant reduction in food intake had occurred. The low-protein diet markedly diminished plasma albumin concentrations and increased plasma $\mathrm{T}_{3}$ values (Table 2). Interscapular BAT weight and cytochrome $c$ oxidase activity (corrected for body weight) were much increased and there was a small rise in the proportion of body fat (Table 3 ).

\section{Treatment with carbimazole}

Rats fed on the low-protein diet and treated with carbimazole showed no changes in BAT weight, cytochrome $c$ oxidase activity or carcass composition when compared with the LP group (Tables 2 and 3). Nevertheless, this drug treatment successfully promoted a significant reduction in total plasma $T_{3}$, resulting in values similar to those for control rats (Table 2). A significant elevation in plasma insulin concentration was observed (Table 2). These hormonal changes accompanied a marked weight gain when compared with LP animals even though food consumption did not differ (Tables 2 and 3). A slight rise in plasma albumin level was observed compared with the LP group, although albumin concentration was still much lower than that for control rats (Table 2).

\section{Treatment with $\alpha$-methyl-para-tyrosine}

Administration of $\alpha$-methyl-p-tyrosine decreased total plasma $T_{3}$ concentration and BAT weight, and increased body fat in relation to the LP group (Tables 2 and 3). A small elevation of plasma albumin concentration was also observed in these drug-treated animals when compared with the LP group, although values were still much lower than those for control rats. Food consumption, in comparison with the other groups, did not change (Table 2). Weight gain was the same as for the LP group and consequently much lower than in control rats (Table 2). Plasma insulin concentration was similar to those of the control and the LP groups and lower than that of the CA group. BAT cytochrome $\mathrm{c}$ oxidase activity was not significantly different to that of the LP rats, although values were higher than for the control and CA groups (Table 3).

\section{Treatment with carbimazole plus $\alpha$-methyl-para-tyrosine}

In the second experiment, animals treated with both thyroid and sympathetic suppressers given simultaneously showed a slight, though not significant, decrease in food intake when compared with LP rats (Table 4). Treatment with carbimazole plus $\alpha$-methyl- $p$-tyrosine promoted greater weight gain associated with a rise in plasma insulin concentration, and higher body fat (Table 6) when compared with the LP and pair-fed groups. Liver weight but not liver protein content was augmented in the pair-fed and CA/MT groups and consequently plasma albumin concentration stayed low as in the other groups.

The hormonal balance characterized by low plasma $T_{3}$ and high plasma insulin concentrations was associated with a reduction in BAT cytochrome $c$ oxidase activity and an increase in body fat (Table 6). No changes in the weight of the gastrocnemius muscle or its protein content were observed (Table 5).

\section{Discussion}

Protein deficiency is a prominent feature of the development of kwashiorkor and marasmic kwashiorkor in children

Table 3. Cytochrome oxidase activity and carcass composition of rats fed on a weaning diet (control), a low-protein diet alone (LP), a low-protein diet plus carbimazole and triiodothyronine (CA) or a low-protein diet plus $\alpha$-methyl-p-tyrosine (MT)* (Values are means for six rats with their pooled standard error)

\begin{tabular}{lcccccc}
\hline & & & & & \multicolumn{2}{c}{ ANOVA } \\
\cline { 5 - 7 } & Control & LP & CA & MT & SEM & $P$ \\
\hline Cytochrome oxidase (U/total BAT per kg body wt) $\dagger$ & $97.5^{\mathrm{a}}$ & $215.4^{\mathrm{bc}}$ & $194 \cdot 6^{\mathrm{b}}$ & $256 \cdot 8^{\mathrm{c}}$ & 12.4 & $<0.001$ \\
$\begin{array}{l}\text { Carcass composition: } \\
\text { body water }(\mathrm{g} / \mathrm{kg})\end{array}$ & $665^{\mathrm{a}}$ & $634^{\mathrm{b}}$ & $639^{\mathrm{b}}$ & $618^{\mathrm{c}}$ & 3 & $<0.001$ \\
$\quad$ body fat $(\mathrm{g} / \mathrm{kg})$ & $92^{\mathrm{a}}$ & $134^{\mathrm{b}}$ & $126^{\mathrm{b}}$ & $155^{\mathrm{c}}$ & 4 & $<0.001$ \\
$\quad$ total body fat $(\mathrm{g})$ & $19.3^{\mathrm{a}}$ & $15 \cdot 6^{\mathrm{b}}$ & $15 \cdot 8^{\mathrm{b}}$ & $20.0^{\mathrm{a}}$ & 0.8 & $<0.01$ \\
\hline
\end{tabular}

BAT, brown adipose tissue.

$a, b, c$ Mean values within a row not sharing a common superscript letter were significantly different, $P<0.05$ (ANOVA followed by the Newman-Keuls procedure).

* For details of diets and procedures, see Table 1 and pp. 456-457.

$+\mathrm{U}$ (units) are defined as $\mu \mathrm{mol}$ reduced cytochrome $\mathrm{c}$ oxidized/min per total interscapular BAT. 
Table 4. Food consumption, weight gain and plasma variables in rats fed on a low-protein diet ad libitum (LP) or a low-protein diet plus carbimazole, triiodothyronine and $\alpha$-methyl-p-tyrosine (CA/MT), and in rats pair-fed with the CA/MT group on a low-protein diet (pair-fed)*

(Values are means for six rats with their pooled standard error)

\begin{tabular}{|c|c|c|c|c|c|}
\hline \multirow[b]{2}{*}{ Group... } & \multirow[b]{2}{*}{ LP } & \multirow[b]{2}{*}{ Pair-fed } & \multirow[b]{2}{*}{ CA/MT } & \multicolumn{2}{|c|}{ ANOVA } \\
\hline & & & & SEM & $P$ \\
\hline $\begin{array}{l}\text { Initial body wt }(\mathrm{g}) \\
\text { Weight gain }(\mathrm{g}) \\
\text { Food consumption: }\end{array}$ & $\begin{array}{l}73 \\
1.2^{a}\end{array}$ & $\begin{array}{c}74 \\
-1.2^{\mathrm{a}}\end{array}$ & $\begin{array}{l}75 \\
15 \cdot 0^{b}\end{array}$ & $\begin{array}{l}6 \\
2 \cdot 1\end{array}$ & $\begin{array}{l}\text { NS } \\
<0.001\end{array}$ \\
\hline $\begin{array}{l}\mathrm{g} / \mathrm{d}) \dagger \\
\left(\mathrm{g} / \mathrm{d} \text { per } \mathrm{kg} \text { body wt } \mathrm{t}^{0.75}\right) \\
\text { Plasma albumin }(\mathrm{g} / \mathrm{l}) \\
\text { Plasma triiodothyronine }(\mu \mathrm{g} / \mathrm{l}) \\
\text { Plasma insulin }(\mathrm{mU} / \mathrm{l})\end{array}$ & $\begin{array}{l}11 \cdot 0 \\
78 \cdot 5 \\
24 \cdot 2 \\
1.46^{\mathrm{a}} \\
13.9^{\mathrm{a}}\end{array}$ & $\begin{array}{c}9.4 \\
66 \cdot 7 \\
25 \cdot 8 \\
1.39^{\mathrm{a}} \\
10.9^{\mathrm{a}}\end{array}$ & $\begin{array}{l}10.1 \\
65.4 \\
26 \cdot 2 \\
0.88^{b} \\
23.8^{b}\end{array}$ & $\begin{array}{l}0.6 \\
4.3 \\
0.6 \\
0.05 \\
3.0\end{array}$ & $\begin{array}{l}\text { NS } \\
\text { NS } \\
\text { NS } \\
<0.001 \\
<0.03\end{array}$ \\
\hline
\end{tabular}

a,b Mean values within a row not sharing a common superscript letter were significantly different, $P<0.05$ (ANOVA followed by the Newman-Keuls procedure).

*For details of diets and procedures, see Table 1 and pp. 456-457.

$\dagger$ Food intake is expressed as the average of daily measurements over 2 weeks.

Table 5. Liver and gastrocnemius variables in rats fed on a low-protein diet ad libitum (LP) or a low-protein diet plus carbimazole, triiodothyronine and $\alpha$-methyl-p-tyrosine (CA/MT), and in rats pair-fed with the CA/MT group on a low-protein diet (pair-fed) ${ }^{*}$ (Values are means for six rats with their pooled standard error)

\begin{tabular}{|c|c|c|c|c|c|}
\hline \multirow[b]{2}{*}{ Group... } & \multirow[b]{2}{*}{ LP } & \multirow[b]{2}{*}{ Pair-fed } & \multirow[b]{2}{*}{ CAMMT } & \multicolumn{2}{|c|}{ ANOVA } \\
\hline & & & & SEM & $P$ \\
\hline $\begin{array}{l}\text { Liver weight ( } \mathrm{g} / \mathrm{kg} \text { body } \mathrm{wt}) \\
\text { Liver protein (mg/liver per } \mathrm{kg} \text { body } \mathrm{wt}) \\
\text { Gastrocnemius muscle (mg/kg body wt) } \\
\text { Gastrocnemius muscle protein (mg/muscle per } \mathrm{kg} \text { body wt) }\end{array}$ & $\begin{array}{l}38 \cdot 6^{\mathrm{a}} \\
6713 \\
5660 \\
1213\end{array}$ & $\begin{array}{l}49 \cdot 0^{b} \\
6980 \\
5563 \\
1229\end{array}$ & $\begin{array}{l}48 \cdot 5^{b} \\
7540 \\
5660 \\
1280\end{array}$ & $\begin{array}{l}1.6 \\
212 \\
135 \\
37\end{array}$ & $\begin{array}{l}0.003 \\
\text { NS } \\
\text { NS } \\
\text { NS }\end{array}$ \\
\hline
\end{tabular}

${ }^{a, b}$ Mean values within a row not sharing a common superscript letter were significantly different, $P<0.05$ (ANOVA followed by the Newman-Keuls procedure).

*For details of diets and procedures, see Table 1 and pp. 456-457.

Table 6. Weight and cytochrome oxidase activity of brown adipose tissue (BAT) and carcass composition of rats fed on a low-protein diet ad libitum (LP) or a low-protein diet carbimazole, triiodothyronine and $\alpha$-methyl-p-tyrosine (CA/MT), and in rats pair-fed with the CA/MT group on a low-protein diet (pair-fed)*

(Values are means for six rats with their pooled standard error)

\begin{tabular}{|c|c|c|c|c|c|}
\hline \multirow[b]{2}{*}{ Group... } & \multirow[b]{2}{*}{$\lfloor P$} & \multirow[b]{2}{*}{ Pair-fed } & \multirow[b]{2}{*}{ CAMMT } & \multicolumn{2}{|c|}{ ANOVA } \\
\hline & & & & SEM & $P$ \\
\hline $\begin{array}{l}\text { Interscapular BAT weight }(\mathrm{mg} / \mathrm{kg} \text { body } \mathrm{wt}) \\
\text { BAT cytochrome oxidase (U/total BAT per } \mathrm{kg} \text { body wt) } \dagger \\
\text { Carcass composition: }\end{array}$ & $\begin{array}{c}5860 \\
450^{\mathrm{a}}\end{array}$ & $\begin{array}{r}4850 \\
461^{\mathrm{a}}\end{array}$ & $\begin{array}{c}5780 \\
277^{b}\end{array}$ & $\begin{array}{r}277 \\
21\end{array}$ & $\begin{array}{l}<0.001 \\
<0.001\end{array}$ \\
\hline $\begin{array}{l}\text { body water }(\mathrm{g} / \mathrm{kg}) \\
\text { body fat }(\mathrm{g} / \mathrm{kg}) \\
\text { total body fat }(\mathrm{g})\end{array}$ & $\begin{array}{l}669^{\mathrm{a}} \\
86 \cdot 7^{\mathrm{a}} \\
6 \cdot 27^{\mathrm{a}}\end{array}$ & $\begin{array}{l}671^{\mathrm{a}} \\
83 \cdot 8^{\mathrm{a}} \\
6 \cdot 08^{\mathrm{a}}\end{array}$ & $\begin{array}{l}638^{\mathrm{b}} \\
129.0^{\mathrm{b}} \\
11.53^{\mathrm{b}}\end{array}$ & $\begin{array}{l}7 \\
8.9 \\
0.93\end{array}$ & $\begin{array}{l}0.01 \\
0.01 \\
0.005\end{array}$ \\
\hline
\end{tabular}

a,b Mean values within a row not sharing a common superscript letter were significantly different, $P<0.05$ (ANOVA followed by the Newman-Keuls procedure).

${ }^{*}$ For details of diets and procedures, see Table 1 and pp. 456-457.

$\dagger U$ (units) are defined as $\mu$ mol reduced cytochrome $c$ oxidized $/ \mathrm{min}$ per total interscapular BAT.

(Whitehead et al. 1977). Studies in developed countries yield perhaps the clearest available evidence that a marked deviation from adequate protein intake itself is the ultimate determinant of human kwashiorkor, leading to severe hypoproteinaemia, hypoalbuminaemia and oedema (Rossouw, 1989). Experimental evidence in animals has shown that a low P:E ratio disrupts the usual response to dietary energy deficiency and leads to hypoalbuminaemia and eventually oedema (Lunn \& Austin, 1983a,b,c; Fiorotto et al. 1987).
The mechanisms by which a low P:E ratio produces hypoalbuminaemia have been partly elucidated in children. Observations in Uganda, where kwashiorkor is the most common form of protein-energy malnutrition, have been contrasted with those in The Gambia, where marasmus is more prevalent (Whitehead et al. 1977). After the first year of life the $P$ : E values of the diets of many Ugandan infants were lower than those of Gambian infants, although energy intakes were similar. Although the Ugandan children grew faster than those in The Gambia, their plasma concentra- 
tions of albumin and cortisol were lower whereas plasma insulin levels were higher. It seems possible, therefore, that insulin plays an essential role in children pre-kwashiorkor by promoting muscle preservation and consequently liver depletion.

In the last 50 years, many experimental studies in rats have attempted to reproduce the symptoms and features of infant kwashiorkor. The results of such studies indicate that rats and other animals offered diets of low protein content voluntarily consume energy well in excess of their requirements (Lunn \& Austin, 1983a,b; Sakuma et al. 1987 ) but are able to dissipate some of this surfeit by a rise in diet-induced thermogenesis (Rothwell et al. 1982), and a concomitant increase in the activity of BAT and noradrenaline turnover (Tyzbir et al. 1981; Rothwell et al. 1983; Emery et al. 1983; Kenovian et al. 1984). On the other hand, other studies have reported increases in body-fat deposition in rats fed on low-protein diets (McCracken, 1975). While many studies have shown repeatedly that consumption of protein-deficient diets by growing rats and other animals causes elevations in circulating levels of blood $\mathrm{T}_{3}$, accompanied by decreases in blood levels of $\mathrm{T}_{4}$ (Tulp et al. 1979; Lunn \& Austin, 1983b,c; Sawaya \& Lunn, 1985; Carew \& Alster, 1997), others have failed to show an elevation of $\mathrm{T}_{3}$ levels in these animals (Makawiti et al. 1995). In a previous study we reported elevated activity of both the thyroid-hormone-sensitive enzymes, mitochondrial $\alpha$-glycerol-3-phosphate dehydrogenase ( $E C$ 1.1.99.5) and $\alpha$-glycerol-3-phosphate shuttle in the liver, and also an increase in the oxidative capacity of BAT in rats fed on a low-protein diet. These findings confirm a higher physiological activity of $\mathrm{T}_{3}$ and noradrenaline in our LP rats (Sawaya \& Lunn, 1985).

The action of $T_{3}$ in muscle and liver protein metabolism is complex. Lunn \& Austin $(1983 b, c)$ found a strong inverse association between plasma albumin levels and blood $\mathrm{T}_{3}$ levels. Clinical and experimental hyperthyroidism stimulates both protein synthesis and degradation in muscle, usually with a net catabolic effect. Recently it has been shown that both chronic and acute hyperthyroidism in normally-fed animals lead to mobilization of muscle $\mathrm{N}$ whereas amino- $\mathrm{N}$ in the liver is spared from irretrievable conversion into urea (Grofte et al. 1997). On the other hand, measurements of protein synthesis in proteindeficient rats showed that the responses of muscle and liver to dietary protein restriction differed (Emery et al. 1983). In liver the depressed protein synthesis was entirely due to a fall in the synthetic activity of RNA, whereas RNA content, but not activity, was the cause of depression of protein synthesis in skeletal muscle, in comparison with normally-fed rats. It is, therefore, difficult to evaluate the actual effects of the specific increase in the level of $\mathrm{T}_{3}$ (but not $\mathrm{T}_{4}$ ) in the blood of protein-deficient animals, found by us and others, and why it is so closely associated with plasma albumin levels. Although, as far as we know, the reason for the elevation in $\mathrm{T}_{3}$ levels is unclear, one possible explanation could be that, in contrast to its catabolic effects on muscle in normally-fed rats, the increased $T_{3}$ and noradrenaline activity may occur as a metabolic consequence of excess carbohydrate intake, and could also act to maintain skeletal muscle protein when dietary protein intake is limited. Clearly, such a mechanism could generate the inappropriate protein distribution and hypoalbuminaemia seen in hyperphagic, protein-deficient rats (Coward et al. 1977, Lunn \& Austin, 1983b,c).

In the present study, we administered two drugs known to lower $\mathrm{T}_{3}$ levels and catacholamine activity and expected to see changes in albumin levels. The administration of either carbimazole or $\alpha$-methyl- $p$-tyrosine alone to rats fed on the low-protein diet did, in fact, result in a small rise in plasma albumin concentration in relation to the non-drugtreated LP group, however, the improvement was very modest. BAT cytochrome $\mathrm{c}$ oxidase activity was not significantly different in rats administered either carbimazole or $\alpha$-methyl-p-tyrosine separately from that in nondrug-treated LP rats. Although we did not measure blood $\mathrm{T}_{4}$ levels in carbimazole-treated rats, whatever its effect was in BAT (a $\mathrm{T}_{4}$-sensitive tissue), it did not affect cytochrome $c$ oxidase activity when the results were compared with those for the LP group.

The simultaneous blocking of thyroid and sympathetic activity, on the other hand, proved to be the most effective treatment for the inhibition of BAT, suggesting that a reduction in the BAT oxidative rate had occurred. Although the administration of both drugs simultaneously through the diet did not significantly impair food intake, they were able to reduce the rate of cytochrome c oxidase activity, and this change was associated with promotion of body-weight gain and with increased body fat. These results confirm that the higher thyroid and sympathetic activities previously observed in rats in response to a low-protein diet are important to the elevation of BAT cytochrome oxidase activity and the promotion of the thermogenic response in these animals (Rothwell et al. 1983; Sawaya \& Lunn, 1985). On the other hand, the lowering of thyroid and sympathetic activity raised plasma insulin levels but did not improve the albuminaemia significantly. Thus, the typical kwashiokor-like dysadaption picture seen in rats fed on low-protein diets, characterized by hepatic depletion (when compared with controls, results not shown) and low plasma albumin levels, still remained in spite of the decrease in BAT oxidative rate after the present drug administration. This indicates that other stimuli were still acting to maintain the dysadapted state and hypoalbuminaemia. In this sense, it is interesting that treatment with these drugs raised plasma insulin values, as a result of the counterregulatory hormonal balance, promoting a marked increase in body fat and muscle preservation. Therefore, the premise that the same mechanisms which control energy expenditure also result in abnormal $\mathrm{N}$ metabolism and dysadaptation was not confirmed. Moreover, the present results seem to indicate that the dysadaptation state is not dependent on the way the organism deals with an excessive energy supply, e.g. storing it as fat or increasing the rate of energy expenditure. Instead, it is possible that the reason for the unchanged hepatic depletion when the CA/MT group is compared with the pair-fed group lies basically in the control of insulin activity in these animals and consequently in the regulation of muscle protein synthesis and degradation.

Several studies have demonstrated the importance of muscle as an organ in which protein metabolism is highly 
responsive to nutrient supply. Muscle has a key role in the sequestration of dietary amino acids after a meal and this mechanism is known to be heavily dependent on insulin concentrations under normal conditions (Tischler, 1981). Crowe \& Royle (1988) found, in rats fed on a low-protein diet $(40 \mathrm{~g} / \mathrm{kg})$, low insulin and plasma glucose concentrations, but increased insulin sensitivity, in these animals when this group was compared with a pair-fed group receiving $144 \mathrm{~g}$ protein $/ \mathrm{kg}$ diet. These results also indicated that it was the reduced protein; carbohydrate ratio rather than the total energy consumed (which in this case was the same) that caused the observed changes in glucose metabolism. If such findings are correct, the overall effect of the increase in insulin sensitivity in rats fed on the lowprotein diet could be enough to cause muscle mass preservation and fat deposition. These factors would then contribute substantially to the characteristic kwashiokorlike symptoms observed in protein-deprived rats, with insulin activity as a primary agent.

In summary, the present study disproves the initial hypothesis which stated that the elevations in thyroid and sympathetic activity were the main causes for liver depletion and consequently hypoalbuminaemia in animals fed on a low-protein diet. On the other hand, the rise in plasma insulin concentration resulting from the reductions in plasma $T_{3}$ level and sympathetic activity supports the hypothesis, described for children with kwashiokor (Whitehead et al. 1977), that insulin activity is a primary key factor in the persistence of the hypoalbuminaemia observed in protein-deficient rats. Therefore, despite the increase in energy dissipation observed in this, and our previous studies, the mechanisms involved in the process seem to be independent of those which cause liver amino acid depletion and consequently hypoalbuminaemia.

\section{Acknowledgements}

We thank Susan Roberts for her advice and assistance in the preparation of the manuscript and Daniel Hoffman for helping in its final version.

\section{References}

Bates PC \& Pell JM (1991) Action and interaction of growth hormone and the $\beta$-agonist, clenbuterol, on growth, body composition and protein turnover in dwarf mice. British Journal of Nutrition 65, 115-129.

Brown JG \& Millward DJ (1983) Dose response of protein turnover in rat skeletal muscle to triiodothyronine treatment. Biochimica et Biophysica Acta 757, 182-190.

Carew BL \& Alster FA (1997) Dietary carbohydrate and fat do not alter the thyroid response to protein deficiency in chicks. Proceedings of the Society for Experimental Biology and Medicine 215, 82-86.

Coward WA, Whitehead RG \& Lunn PG (1977) Reasons why hypoalbuminaemia may or may not appear in protein-energy malnutrition. British Joumal of Nutrition 38, 115-126.

Crowe PJ \& Royle GT (1988) Glucose kinetics in protein depletion-effect of glucose infusion in the fasted rat. Journal of Nutrition 118, 1240-1244.
Emery PW, Rothwell NJ \& Stock MJ (1983) Protein synthesis in liver, skeletal muscle, and brown adipose tissue of rats fed a protein-deficient diet. Bioscience Reports 3, 569-575.

Emery PW, Rothwell NJ, Stock MJ \& Winter PD (1984) Chronic effects of $\beta$-adrenergic agonists on body composition and protein synthesis in the rat. Bioscience Reports 4, 83-91.

Fiorotto ML, Sheng H, Evans HJ, Leblanc AD, Johnson PC \& Nichols BL (1987) Specific effects of weight loss, protein deficiency and energy deprivation on the water and electrolyte composition of young rats. Journal of Nutrition 117, 933-940.

Grofte T, Wolthers T, Moller N, Jorgensen JOL, Flyvbjerg A \& Orskov H (1997) Moderate hyperthyroidism reduces liver amino nitrogen conversion, muscle nitrogen contents and overall nitrogen balance in rats. European Journal of Clinical Investigation 27, 85-92.

Kenovian AV, Vander Tuig JG \& Romsos DR (1984) Consumption of a low-protein diet increases norepinephrine turnover in brown adipose tissue of adult rats. Journal of Nutrition 114, 543-550.

Lunn PG \& Austin S (1983a) Differences in nitrogen metabolism between protein-deficient and energy-deficient rats with similarly restricted growth rates. Annals of Nutrition and Metabolism 27, 242-251

Lunn PG \& Austin S (1983b) Excess energy intake promotes the development of hypoalbuminaemia in rats fed on low-protein diets. British Journal of Nutrition 49, 9-16.

Lunn PG \& Austin S (1983c) Dietary manipulation of plasma albumin concentration. Journal of Nutrition 113, 1791-1802.

McCracken KJ (1975) Effect of feeding pattern on the energy metabolism of rats given low-protein diets. British Joumal of Nutrition 33, 277-289.

Makawiti DW, Lomo PO, Konji VN \& Oloowokere JO (1995) Altered 3,5,3'-triiodothyronine thyroxine ratio in experimentally induced kwashiorkor and obesity in rats. International Journal for Vitamin and Nutrition Research 65 , 132-136.

Peavy DE, Taylor JM \& Jefferson LS (1981a) Protein synthesis in perfused rat liver following thyroidectomy and hormone treatment. American Journal of Physiology 240, E18-E23.

Peavy DE, Taylor JM \& Jefferson LS (1981b) Alterations in albumin secretion and total protein synthesis in livers of thyroidectomised rats. Biochemical Journal 198, 289-299.

Rossouw JE (1989) Kwashiorkor in North America. American Journal of Clinical Nutrition 49, 588-592.

Rothwell NJ, Stock MJ \& Tyzbir RS (1982) Energy balance and mitochondrial function in liver and brown fat of rats fed "cafeteria" diets of varying protein content. Journal of Nutrition 112, 1663-1668.

Rothwell NJ, Stock MJ \& Tyzbir RS (1983) Mechanisms of thermogenesis induced by low-protein diets. Metabolism 32, 257-262.

Sakuma K, Ohyama T, Sogawa K, Fujii-Kuriyama Y \& Matsumura Y (1987) Low-protein-high-energy diet induces repressed transcription of albumin mRNA in rat liver. Journal of Nutrition 117, 1141-1148.

Sawaya AL \& Lumn PG (1985) Evidence suggesting that the plasma triodothyronine concentration of rats fed on protein deficient diets is physiologically active. British Journal of Nutrition 53, 175-181.

Sheng HP \& Huggins RA (1979) A review in body composition studies with emphasis on total body water and fat. American Journal of Clinical Nutrition 32, 630-637.

Tischler ME (1981) Hormonal regulation of protein degradation in skeletal and cardiac muscle. Life Science 22, 2569-2570.

Tulp OL, Krupp PP, Danforth E Jr \& Horton ES (1979) Characteristics of thyroid function in experimental protein malnutrition. Journal of Nutrition 109, 1321-1329. 
Tyzbir RS, Kunin AS, Sims NM \& Danforth E Jr (1981) Influence of diet composition on serum $\mathrm{T}_{3}$ concentration, hepatic mitochondrial metabolism and shuttle system activity in rats. Journal of Nutrition 111, 252-260.

Vander Tuig JG \& Romsos DR (1984) Effects of dietary carbohydrate, fat and protein on norepinephrine turnover in rats. Metabolism 33, 26-30.
Whitehead RG, Coward WA, Lunn PG \& Rutishauser I (1977) A comparison of the pathogenesis of protein-energy malnutrition in Uganda and the Gambia. Transactions of the Royal Society of Tropical Medicine and Hygiene 71, 189-195.

Yonetani T \& Ray GS (1965) Method for measurements of cytochrome c oxidase. Journal of Biological Chemistry 240 , 3392-3399. 